\title{
BMJ Open Is having a family member with chronic health concerns bad for young people's health? Cross-sectional evidence from a national survey of young Australians
}

\author{
Anna K Moffat, ${ }^{1}$ Gerry Redmond ${ }^{2}$
}

To cite: Moffat AK, Redmond G. Is having a family member with chronic health concerns bad for young people's health? Cross-sectional evidence from a national survey of young Australians. BMJ Open 2017;7:e013946.

doi:10.1136/bmjopen-2016013946

- Prepublication history and additional material is available. To view please visit the journal (http://dx.doi.org/ 10.1136/bmjopen-2016013946).

Received 24 August 2016 Revised 29 November 2016 Accepted 9 December 2016

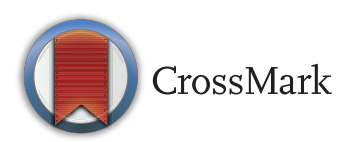

${ }^{1}$ School of Pharmacy and Medical Sciences, University of South Australia, Adelaide, South Australia, Australia ${ }^{2}$ School of Social and Policy Studies, Flinders University, Adelaide, South Australia, Australia

Correspondence to Dr Anna K Moffat; anna.moffat@unisa.edu.au

\section{ABSTRACT}

Objectives: Young people's perspectives on the association between having a family member with a chronic health concern (FHC) and their own health are under-researched. This study used young people's reports to assess the prevalence of FHCs and their association with negative health outcomes, with an aim of identifying potential inequalities between marginalised and non-marginalised young people. Family cohesion was examined as a moderating factor.

Design: Cross-sectional data from the Australian Child Wellbeing Project survey were used.

Respondents were asked whether someone in their family experienced one or more FHCs (disability, mental illness or drug/alcohol addiction). In addition, their experience of different psychosomatic symptoms (headache, sleeplessness, irritability, etc), aspects of family relationships and social and economic characteristics (disability, materially disadvantaged and Indigenous) were documented.

Setting: Nationally representative Australian sample.

Participants: 1531 students in school years 4 and 6 and 3846 students in year 8 .

Results: A quarter of students reported having an FHC (years 4 and 6: $23.96 \%(95 \% \mathrm{Cl} 19.30 \%$ to $28.62 \%)$; year 8 : $25.35 \%$ (95\% Cl $22.77 \%$ to $27.94 \%)$ ). Significantly, more students with FHCs than those without reported experiencing 2 or more negative health symptoms at least weekly $(\mathrm{OR}=1.78$; $95 \% \mathrm{Cl} 1.19$ to $2.65 ; \mathrm{p}<0.01)$. However, an independent relationship between $\mathrm{FHCs}$ and symptom load was only found in the case of FHC-drug/alcohol addiction. Marginalised students and students reporting low family cohesion had an increased prevalence of FHCs and notably higher symptom loads where FHCs were present. Level of family cohesion did not impact the relationship between FHCs and symptom load.

Conclusions: The burden of FHCs is inequitably distributed between marginalised and nonmarginalised groups, and between young people experiencing different levels of family cohesion. More work is required regarding appropriate targets for community and family-level interventions to support young people in the context of FHCs.

\section{Strengths and limitations of this study}

- The study provides nationally representative estimates of FHCs and associated characteristics as reported by young people aged 9-14 years.

- Unlike most small-scale studies of FHCs, the survey used in this study allowed comparison of health among subsamples with and without FHCs, by age, sex, marginalisation and family cohesion.

- The survey used in this study asked young people to report on a broad range of social and economic circumstances that allowed robust identification of marginalisation and assessment of family cohesion.

- Causation is unable to be established due to cross-sectional study design.

\section{INTRODUCTION}

There is now a growing literature showing how social and environmental factors can influence young people's health, engagement in peer activities, cognitive development and well-being. ${ }^{1}{ }^{2}$ Having a family member who experiences a chronic and/or debilitating health concern (FHC) is one such factor. ${ }^{3-8}$ Previous estimates of FHC prevalence have often focused on specific health concerns involving just parents or siblings, use parent, as opposed to child, report $^{9}$ or have used data obtained from high-risk samples such as those who access mental health or substance abuse services. ${ }^{9-11}$ However, limited available evidence suggests that many young people experience FHCs. One study of 9-20-year olds in a large school and community-based survey in Australia found that $29 \%$ reported a serious physical or mental health condition in a family member. ${ }^{7}$ However, this study did not make claims to national representativeness. FHCs are known stressors that can impact a variety of long-term outcomes for children and young people. For example, children who 
grow up with a parent with a mental illness are more likely to experience depression and substance use later in life. ${ }^{12}{ }^{13}$ Therefore, investigations of prevalence and associations with health are important.

In the Australian context, young people who are materially disadvantaged, Indigenous and/or have a disability can be expected to have higher rates of FHCs. Globally, and in Australia, poverty is associated with high rates of disability, ${ }^{14}{ }^{15}$ mental health concerns and substance use. ${ }^{16}$ Research also suggests a higher prevalence of substance use, disability, chronic illness and mental health concerns among Indigenous Australians than among non-Indigenous Australians. ${ }^{17-20}$ Further, young people who are themselves living with disability are more likely than young people without disability to have parents with disability or mental health concerns. ${ }^{21-23}$

Given the likely inequalities in the distribution of FHCs across different groups in Australia, understanding the association between FHCs and young people's wellbeing is important. Studies have shown that children with seriously ill family members have internalising and externalising problem behaviour ${ }^{8}$ and a range of negative social, psychological, somatic effects and overall health effects, albeit with often small effect sizes. ${ }^{7}$

That an association between FHCs and young people's health has been found is not surprising, given that experience of frequent psychosomatic health symptoms is often associated with stress in a person's environment. ${ }^{2425}$ Most often, psychosomatic symptoms occur in clusters, ${ }^{24} 26$ with frequency of two or more symptoms per week considered to reflect a high symptom load for a young person. ${ }^{1}$ Since multiple stressors in childhood can have a cumulative effect that is associated with exponentially worse outcomes, ${ }^{1}{ }^{27} 28$ it is expected that marginalisation and FHCs would have large negative impacts on the health of young people. However, the effects of demographic characteristics on the relationship between FHCs and outcomes are disputed. ${ }^{78}$ For example, while Sieh $e t a l^{8}$ found no overall effect of gender on the relationship between FHCs and young people's outcomes, Pakenham and $\mathrm{Cox}^{7}$ showed more somatisation for girls than for boys, which they suggested may be because girls are more likely to take on caring roles than boys.

These disparities in results may be due to family relationship variables not previously considered in the association between FHCs and health outcomes in young people. Strong family cohesion (feelings of closeness and emotional bond between family members) ${ }^{29}$ has been shown to serve as a protective factor against poorer outcomes, especially for adolescents, in the presence of family violence and substance use. ${ }^{30}{ }^{31}$ It has also been shown to attenuate the risk for internet addiction, ${ }^{32}$ adolescent alcohol use, ${ }^{33}$ problem gambling in youth ${ }^{34}$ and increase resilience and schooling outcomes, even in the context of material disadvantage. ${ }^{35} 36$ Therefore, high family cohesion would be expected to be associated with lower symptom load in young people, even when FHCs are present.
The purpose of this paper is therefore to explore the relationship between FHCs and health outcomes in a nationally representative sample of young Australians aged 9-14 years. The following questions are explored:

1. Does the prevalence of FHCs vary with young people's age, sex and marginalised status?

2. Are the odds of having a high symptom load greater for young people with FHCs, controlling for age, sex and marginalised status?

3. Does family cohesion modify the relationship between FHCs and symptom load?

\section{METHODS \\ Data}

Data were drawn from a survey conducted in late 2014 as part of the Australian Child Wellbeing Project (ACWPhttp://www.australianchildwellbeing.com.au). The survey instrument was developed following direct consultations with 97 young people in 9 groups on what contributes to a 'good life' ${ }^{37}$ A multistage stratified probability sample (states/territories, sectors and schools) was used to arrive at a nationally representative sample of students in years 4,6 and 8 ( 9-10, 11-12 and 13-14 years old). ${ }^{38}$ Jurisdictional educational authorities and university human research ethics committees approved the research. Informed parental and student consent was obtained in all cases. The final sample comprised 5440 valid student responses from 180 schools in every state and territory. This represents a response rate of $38 \%$ at the school level and $33 \%$ at the student level within participating schools. The student participation rate was impacted by active consent procedures, where students and their parents had to sign consent forms. Population weights were applied to adjust for school and studentlevel non-response, and ensure that the analysis sample was representative of Australian students in school years 4, 6 and 8 (for further information, see ref. 37).

Identifying FHCs: students were asked: "Is there anyone in your family who is seriously affected by: (1) disability or long term illness, (2) depression or mental illness, or (3) using alcohol or other drugs?" Students could select any combination of the three conditions or "none of these." This question was taken, slightly modified, from the New Zealand Youth 2000 Survey Series. ${ }^{39}$ In the New Zealand survey, respondents were asked whether anyone in their home had an FHC. In the present study, the question was changed in response to direct consultations with young people who stressed the importance of family for 'the good life' and the distinction many of them made between 'family' and 'household'. ${ }^{37}$

Symptom load: The HBSC Symptom Checklist ${ }^{40}$ was used to measure psychological and somatic symptom load. Students were asked: "In the last 6 months: how often have you had the following?" Eight symptoms were listed-feeling low, irritability or bad temper, feeling nervous, headache, stomach-ache, backache, sleeplessness and feeling dizzy. Responses were selected from (0) 
'seldom or never' to (4) 'almost daily'. Consistent with other studies, a binary variable was derived to identify respondents who experienced at least two of the eight symptoms at least once a week, indicating a high psychosomatic symptom load. ${ }^{1}$

Marginalised groups: Material deprivation was assessed using responses to four questions: how many cars, vans or trucks the student's family owned, whether the student had their own bedroom, how many times the student travelled away on holiday with their family in the past year and how many computers the family owned. These questions have been widely used as a proxy for socioeconomic status in surveys of young people. ${ }^{41} 42$ The resulting scale differentiated effectively between young people who were materially disadvantaged $(12.9 \%$ of years 4 and $6 \mathrm{~s}$, and $8.3 \%$ of year $8 \mathrm{~s}$ ) and those who were not. ${ }^{37}$

Young people with disability were identified by responding 'yes' to a question asking whether they had a disability and in addition indicating that the disability made it hard for them to, or stopped them doing, one or more activities (years 4 and 6: 11.3\%; year 8: 11.0\%). Students self-identified in the survey as Indigenous (years 4 and 6: $7.0 \%$; year 8: $3.5 \%$ ).

As described by Redmond et $a l,{ }^{37}$ there is significant overlap in students who identify as being in one or more of these marginalised groups. There is also considerable diversity within these groups. However, they share common factors, such as minority status in the Australian context, and health, educational and economic disadvantages that are greater than what is seen in non-marginalised groups on average. ${ }^{37}$ Where reference is made to non-marginalised students, this group comprises those not included in any of the three above marginalised groups.

Family cohesion: Family cohesion was measured using a family cohesion scale from the international Children's Worlds survey which aims to measure belonging and emotional bonding young people feel within their family. ${ }^{43}$ Students were asked: "how often in the past week have you spent time doing the following things with your family?" Students rated the frequency of "talking together," "laughing together" and "learning together" from (0) "not at all last week" to (3) "every day last week." Students could also code (4) "Don't know." These three items loaded onto a family cohesion scale $(\alpha=0.74$; factor loadings $=0.72-0.92, \quad \mathrm{p}<0.001)$, the structure of which was invariant across respondents with and without an FHC $\quad\left(\chi^{2} \quad(\mathrm{df}=8 \quad \mathrm{~N}=4534)=32.48, \quad \mathrm{p}<0.001 ; \quad \mathrm{CFI}=0.997\right.$; RMSEA $=0.037)$. Total family cohesion scores were calculated by summing the three variables to create a total score ranging from 0 to 9 . In this analysis, a three-category indicator was used, representing low (score $=0-4$ ), average (5-7) and high (8-9) levels of cohesion, with the bottom and top categories each containing about $15 \%$ of all observations. Students who did not give a response to at least one of the three items, or who responded 'I don't know', were excluded from the analysis.

\section{Statistical methods}

Analysis was performed using Stata/SE V.14 for Windows (copyright 1985-2015 StataCorp LP). Complex survey design weights were applied, adjusting for differential non-response in terms of state/territory, school sector and socioeconomic status, and student sex. The prevalence of FHCs was examined overall, and by age, sex and marginalisation. Mean symptom loads were compared across students with and without FHCs by age, sex, marginalisation and family cohesion. Ninety-five per cent CIs were calculated for all means and percentages. T-tests were employed to assess the significance of differences between means and percentages. Logistic regression was used to examine the overall relationship between the different categories of FHC and experience of two or more health symptoms at least weekly, controlling for the effects of age, sex and marginalised status on this relationship, and whether family cohesion modified the relationship. Observations with missing data were excluded from parts of the analysis. Data on FHCs were missing for $13 / 1544$ years 4 and 6 students $(0.8 \%)$, and $50 / 3896$ year 8 students $(1.3 \%)$. Where all variables were included in the multivariate analysis, the level of missings was higher (338/1544 at years 4 and 6-21.9\%; $865 / 3896$ at year $8-22.2 \%$ ). The majority of these missings came from missing data relating to the symptom load and family cohesion scales. Tests indicated that when missing values for these scales were imputed, results (with one exception, noted below) were not significantly different from those reported in this paper (see the online supplementary file).

\section{RESULTS}

Table 1 shows that approximately one-quarter of students in both age groups reported an FHC. The most common was disability/long-term illness, followed by depression/mental illness and then drugs/alcohol addiction. Among years 4 and 6 students, there was little difference in the percentages of boys and girls reporting FHCs. Among year 8 students, however, girls were significantly more likely than boys to report an FHC. In both age groups, students who were materially disadvantaged, students with disability and Indigenous students were considerably more likely to report all types of FHC than non-marginalised students.

Table 1 also shows that there is little relationship between family cohesion and FHCs among younger students (note, however, where missing values are imputed, a stronger relationship is apparent-see the online supplementary file). Among year $8 \mathrm{~s}$ on the other hand, students reporting high family cohesion are notably less likely to report that someone in their family has mental illness/depression or drug/alcohol addiction, although proportions with low and high family cohesion reporting disability/chronic illness are similar.

Table 2 shows that among younger and older students, proportions reporting high symptom load (two or more 


\begin{tabular}{|c|c|c|c|c|c|}
\hline & $\begin{array}{l}\text { Disability/ } \\
\text { long-term illness }\end{array}$ & $\begin{array}{l}\text { Depression/ } \\
\text { mental illness }\end{array}$ & $\begin{array}{l}\text { Drugs/alcohol } \\
\text { addiction }\end{array}$ & FHC overall & $\mathbf{N}$ \\
\hline Years 4 and 6 & & & & & $\begin{array}{l}\text { Year level } \\
\text { total }=1544\end{array}$ \\
\hline All & $\begin{array}{l}14.20 \\
(9.88-18.52)\end{array}$ & $\begin{array}{l}8.60 \\
(6.21-10.99)\end{array}$ & $\begin{array}{l}7.46 \\
(4.72-10.21)\end{array}$ & $\begin{array}{l}23.96 \\
(19.30-28.62)\end{array}$ & 1531 \\
\hline Boys & $\begin{array}{l}13.70 \\
(8.01-19.39)\end{array}$ & $\begin{array}{l}7.53 \\
(3.49-11.58)\end{array}$ & $\begin{array}{l}7.08 \\
(3.4-10.77)\end{array}$ & $\begin{array}{l}23.98 \\
(17.22-30.74)\end{array}$ & 656 \\
\hline Girls & $\begin{array}{l}14.73 \\
(10.53-18.93)\end{array}$ & $\begin{array}{l}9.72 \\
(6.94-12.5)\end{array}$ & $\begin{array}{l}7.87 \\
(4.66-11.07)\end{array}$ & $\begin{array}{l}23.94 \\
(19.16-28.72)\end{array}$ & 875 \\
\hline Materially disadvantaged & $\begin{array}{l}22.23 \\
(13.08-31.39)\end{array}$ & $\begin{array}{l}14.52 \\
(9.1-19.93)\end{array}$ & $\begin{array}{l}11.05 \\
(3.95-18.15)\end{array}$ & $\begin{array}{l}38.54 \\
(25.4-51.69)\end{array}$ & 172 \\
\hline With disability & $\begin{array}{l}26.85 \\
(20.82-32.89)\end{array}$ & $\begin{array}{l}13.51 \\
(6.16-20.86)\end{array}$ & $\begin{array}{l}13.84 \\
(6.87-20.82)\end{array}$ & $\begin{array}{l}41.93 \\
(31.23-52.63)\end{array}$ & 193 \\
\hline Indigenous & $\begin{array}{l}29.34 \\
(18.39-40.29)\end{array}$ & $\begin{array}{l}6.19 \\
(1.29-11.09)\end{array}$ & $\begin{array}{l}14.93 \\
(5.85-24.01)\end{array}$ & $\begin{array}{l}40.18 \\
(29.93-50.43)\end{array}$ & 106 \\
\hline Not marginalised & $\begin{array}{l}10.69 \\
(6.84-14.54)\end{array}$ & $\begin{array}{l}7.25 \\
(4.83-9.67)\end{array}$ & $\begin{array}{l}5.96 \\
(3.04-8.88)\end{array}$ & $\begin{array}{l}18.92 \\
(15.15-22.69)\end{array}$ & 1112 \\
\hline Low family cohesion & $\begin{array}{l}11.72 \\
(7.45-15.98)\end{array}$ & $\begin{array}{l}9.51 \\
(5.35-13.67)\end{array}$ & $\begin{array}{l}9.31 \\
(5.16-13.46)\end{array}$ & $\begin{array}{l}21.16 \\
(15.5-26.81)\end{array}$ & 244 \\
\hline Average family cohesion & $\begin{array}{l}11.47 \\
(7.32-15.62)\end{array}$ & $\begin{array}{l}7.12 \\
(4.1-10.15)\end{array}$ & $\begin{array}{l}5.91 \\
(2.85-8.97)\end{array}$ & $\begin{array}{l}20.68 \\
(15.94-25.42)\end{array}$ & 672 \\
\hline High family cohesion & $\begin{array}{l}11.84 \\
(7.35-16.33)\end{array}$ & $\begin{array}{l}8.79 \\
(3.32-14.25)\end{array}$ & $\begin{array}{l}6.01 \\
(0.45-11.57)\end{array}$ & $\begin{array}{l}20.96 \\
(13.68-28.23)\end{array}$ & 385 \\
\hline Year 8 & & & & & $\begin{array}{l}\text { Year level } \\
\text { total=3896 }\end{array}$ \\
\hline All & $\begin{array}{l}13.68 \\
(12.27-15.1)\end{array}$ & $\begin{array}{l}11.53 \\
(9.57-13.48)\end{array}$ & $\begin{array}{l}7.78 \\
(6.35-9.21)\end{array}$ & $\begin{array}{l}25.35 \\
(22.77-27.94)\end{array}$ & 3846 \\
\hline Boys & $\begin{array}{l}12.23 \\
(10.61-13.85)\end{array}$ & $\begin{array}{l}8.02 \\
(6.05-9.98)\end{array}$ & $\begin{array}{l}6.81 \\
(4.91-8.72)\end{array}$ & $\begin{array}{l}21.73 \\
(18.87-24.58)\end{array}$ & 1922 \\
\hline Girls & $\begin{array}{l}15.18 \\
(13.14-17.23)\end{array}$ & $\begin{array}{l}15.16 \\
(12.49-17.83)\end{array}$ & $\begin{array}{l}8.78 \\
(6.86-10.71)\end{array}$ & $\begin{array}{l}29.10 \\
(25.59-32.61)\end{array}$ & 1924 \\
\hline Materially disadvantaged & $\begin{array}{l}28.92 \\
(23.94-33.91)\end{array}$ & $\begin{array}{l}26.51 \\
(20.97-32.04)\end{array}$ & $\begin{array}{l}17.51 \\
(12.27-22.76)\end{array}$ & $\begin{array}{l}50.21 \\
(44.79-55.64)\end{array}$ & 397 \\
\hline With disability & $\begin{array}{l}19.43 \\
(13.11-25.75)\end{array}$ & $\begin{array}{l}19.37 \\
(13.41-25.32)\end{array}$ & $\begin{array}{l}12.92 \\
(7.29-18.55)\end{array}$ & $\begin{array}{l}35.05 \\
(27.21-42.88)\end{array}$ & 312 \\
\hline Indigenous & $\begin{array}{l}22.76 \\
(15.52-30)\end{array}$ & $\begin{array}{l}17.40 \\
(7.58-27.22)\end{array}$ & $\begin{array}{l}15.93 \\
(6.47-25.4)\end{array}$ & $\begin{array}{l}42.44 \\
(34.96-49.93)\end{array}$ & 133 \\
\hline Not marginalised & $\begin{array}{l}10.73 \\
(9.26-12.21)\end{array}$ & $\begin{array}{l}8.90 \\
(6.82-10.99)\end{array}$ & $\begin{array}{l}5.77 \\
(4.48-7.06)\end{array}$ & $\begin{array}{l}20.42 \\
(17.83-23.02)\end{array}$ & 2997 \\
\hline Low family cohesion & $\begin{array}{l}16.08 \\
(13.03-19.12)\end{array}$ & $\begin{array}{l}19.34 \\
(15.24-23.44)\end{array}$ & $\begin{array}{l}13.48 \\
(10.27-16.69)\end{array}$ & $\begin{array}{l}33.57 \\
(29.12-38.02)\end{array}$ & 897 \\
\hline Average family cohesion & $\begin{array}{l}11.51 \\
(9.45-13.56)\end{array}$ & $\begin{array}{l}9.80 \\
(7.91-11.69)\end{array}$ & $\begin{array}{l}6.30 \\
(4.83-7.77)\end{array}$ & $\begin{array}{l}22.34 \\
(19.5-25.18)\end{array}$ & 1715 \\
\hline High family cohesion & $\begin{array}{l}15.79 \\
(11.37-20.21)\end{array}$ & $\begin{array}{l}6.07 \\
(3.8-8.34)\end{array}$ & $\begin{array}{l}2.82 \\
(1.34-4.3)\end{array}$ & $\begin{array}{l}20.97 \\
(16.36-25.57)\end{array}$ & 730 \\
\hline
\end{tabular}

$\%$ are weighted; $95 \%$ Cls are reported in parentheses. Ns are unweighted. Source: ACWP survey, authors' calculations. 
Table 2 Symptom load by FHC, gender, marginalisation and family cohesion

\begin{tabular}{|c|c|c|c|c|c|c|c|}
\hline & & \multicolumn{3}{|l|}{ Years 4 and 6} & \multicolumn{3}{|l|}{ Year 8} \\
\hline & & No FHC & FHC & & No FHC & FHC & \\
\hline \multirow[t]{2}{*}{ All } & $\%$ & $\begin{array}{l}27.74 \\
(24.93-30.55)\end{array}$ & $\begin{array}{l}48.72 \\
(42.11-55.33)\end{array}$ & $* * *$ & $\begin{array}{l}24.29 \\
(22.38-26.2)\end{array}$ & $\begin{array}{l}44.24 \\
(40.16-48.32)\end{array}$ & *** \\
\hline & $\mathrm{N}$ & 1096 & 312 & & 2647 & 859 & \\
\hline \multirow[t]{2}{*}{ Boy } & $\%$ & $\begin{array}{l}26.58 \\
(21.94-31.22)\end{array}$ & $\begin{array}{l}44.62 \\
(35.67-53.56)\end{array}$ & ** & $\begin{array}{l}21.66 \\
(18.7-24.61)\end{array}$ & $\begin{array}{l}36.18 \\
(30.79-41.57)\end{array}$ & $* * *$ \\
\hline & $\mathrm{N}$ & 474 & 130 & & 1362 & 351 & \\
\hline \multirow[t]{2}{*}{ Girl } & $\%$ & $\begin{array}{l}28.62 \\
(24.98-32.26)\end{array}$ & $\begin{array}{l}51.65 \\
(43.25-60.05)\end{array}$ & $\star \star \star *$ & $\begin{array}{l}27.08 \\
(24.4-29.77)\end{array}$ & $\begin{array}{l}49.80 \\
(45.5-54.11)\end{array}$ & *** \\
\hline & $\mathrm{N}$ & 622 & 182 & & $\begin{array}{l}1285 \\
*\end{array}$ & 508 & \\
\hline \multirow[t]{2}{*}{ With disability } & $\%$ & $\begin{array}{l}50.00 \\
(38.97-61.03)\end{array}$ & $\begin{array}{l}65.63 \\
(53.33-77.92)\end{array}$ & & $\begin{array}{l}46.49 \\
(39.24-53.74)\end{array}$ & $\begin{array}{l}64.37 \\
(57.59-71.15)\end{array}$ & *** \\
\hline & $\mathrm{N}$ & 86 & 64 & & 185 & 174 & \\
\hline p(disability>not marginalised) & & $* \star \star$ & $* *$ & & $* * *$ & $* * *$ & \\
\hline \multirow[t]{2}{*}{ Materially disadvantaged } & $\%$ & $\begin{array}{l}38.39 \\
(29.38-47.4)\end{array}$ & $\begin{array}{l}51.67 \\
(39.65-63.68)\end{array}$ & * & $\begin{array}{l}33.52 \\
(26.55-40.5)\end{array}$ & $\begin{array}{l}52.73 \\
(41.5-63.95)\end{array}$ & ** \\
\hline & $\mathrm{N}$ & $\begin{array}{l}112 \\
* *\end{array}$ & 60 & & 176 & $\begin{array}{l}110 \\
*\end{array}$ & \\
\hline Indigenous & $\%$ & $\begin{array}{l}36.84 \\
(24.44-49.24)\end{array}$ & $\begin{array}{l}46.88 \\
(29.67-64.08)\end{array}$ & & $\begin{array}{l}37.68 \\
(25.32-50.04)\end{array}$ & $\begin{array}{l}33.33 \\
(19.32-47.35)\end{array}$ & \\
\hline p(Indigenous>not marginalised) & $\mathrm{N}$ & 57 & 32 & & $\begin{array}{l}69 \\
*\end{array}$ & 48 & \\
\hline Not marginalised & $\%$ & $\begin{array}{l}24.80 \\
(21.74-27.85)\end{array}$ & $\begin{array}{l}45.95 \\
(38.24-53.66)\end{array}$ & $* \star *$ & $\begin{array}{l}21.80 \\
(19.77-23.84)\end{array}$ & $\begin{array}{l}38.76 \\
(34.13-43.39)\end{array}$ & *** \\
\hline p(marginalised $>$ not marginalised) & $\mathrm{N}$ & $\begin{array}{l}859 \\
* \star \star\end{array}$ & 185 & & 2229 & 565 & \\
\hline \multirow[t]{2}{*}{ Low family cohesion (scale score-0-4) } & $\%$ & $\begin{array}{l}36.21 \\
(26.71-45.7)\end{array}$ & $\begin{array}{l}63.33 \\
(52.72-73.94)\end{array}$ & $* \star *$ & $\begin{array}{l}39.62 \\
(34.79-44.46)\end{array}$ & $\begin{array}{l}62.72 \\
(56.04-69.41)\end{array}$ & *** \\
\hline & $\mathrm{N}$ & 174 & 60 & & 530 & 279 & \\
\hline \multirow[t]{2}{*}{ 'Average' family cohesion (scale score-5-7) } & $\%$ & $\begin{array}{l}28.92 \\
(24.58-33.26)\end{array}$ & $\begin{array}{l}45.26 \\
(35.99-54.52)\end{array}$ & ** & $\begin{array}{l}19.90 \\
(17.63-22.18)\end{array}$ & $\begin{array}{l}33.05 \\
(26.97-39.13)\end{array}$ & *** \\
\hline & $\mathrm{N}$ & 491 & 137 & & 1221 & 357 & \\
\hline \multirow[t]{2}{*}{ High family cohesion (scale score-8-9) } & $\%$ & $\begin{array}{l}18.00 \\
(14.54-21.46)\end{array}$ & $\begin{array}{l}38.71 \\
(26.75-50.67)\end{array}$ & ** & $\begin{array}{l}14.59 \\
(11.53-17.66)\end{array}$ & $\begin{array}{l}31.03 \\
(22.9-39.17)\end{array}$ & *** \\
\hline & $\mathrm{N}$ & 300 & 62 & & 555 & 116 & \\
\hline p(low cohesion>high cohesion) & & *** & ** & & $\star \star \star *$ & $\star * \star *$ & \\
\hline
\end{tabular}

Note: \% are weighted; 95\% Cls are reported in parentheses. Ns are unweighted. Astericks' in columns denote significance of difference between FHC and non-FHC samples; $\mathrm{p}$ values in rows denote significance of difference between groups within FHC and non-FHC samples; ${ }^{*} p<0.05,{ }^{* *} p<0.01,{ }^{* * *} p<0.001$. Source: ACWP survey, authors' calculations. 
Table 3 ORs for marginalised and non-marginalised students in years 4 and 6 and year 8 experiencing 2+ health symptoms at least weekly, controlling for the presence of $\mathrm{FHC}$

\begin{tabular}{|c|c|c|c|c|c|c|c|c|c|c|}
\hline & \multirow{2}{*}{\multicolumn{2}{|c|}{$\frac{\text { Model } 1}{\text { Variables }}$}} & \multirow{2}{*}{\multicolumn{2}{|c|}{$\begin{array}{l}\text { Model } 2 \\
\text { FHC disability }\end{array}$}} & \multirow{2}{*}{\multicolumn{2}{|c|}{$\begin{array}{l}\text { Model } 3 \\
\text { FHC mental illness }\end{array}$}} & \multirow{2}{*}{\multicolumn{2}{|c|}{$\begin{array}{l}\text { Model } 4 \\
\text { FHC drug/alcohol }\end{array}$}} & \multirow{2}{*}{\multicolumn{2}{|c|}{$\frac{\text { Model } 5}{\text { Any FHC }}$}} \\
\hline & & & & & & & & & & \\
\hline & OR & $95 \% \mathrm{Cl}$ & $\overline{\text { OR }}$ & $95 \% \mathrm{Cl}$ & $\overline{\text { OR }}$ & $95 \% \mathrm{Cl}$ & OR & $95 \% \mathrm{Cl}$ & OR & $95 \% \mathrm{Cl}$ \\
\hline & & - & & - & & - & & - & & - \\
\hline Year 8 & $0.796^{\star \star \star}$ & 0.682 to 0.928 & $0.764^{\star \star \star}$ & 0.647 to 0.902 & $0.757^{\star \star \star}$ & 0.643 to 0.892 & $0.825^{\star \star}$ & 0.702 to 0.970 & $0.793^{\star \star}$ & 0.662 to 0.951 \\
\hline Girl & $1.391^{\star * *}$ & 1.209 to 1.601 & $1.341^{\star \star \star}$ & 1.151 to 1.562 & $1.276^{\star \star \star}$ & 1.097 to 1.484 & $1.385^{\star \star \star}$ & 1.195 to 1.604 & $1.261^{* * *}$ & 1.067 to 1.491 \\
\hline Disability & $3.192^{\star \star \star}$ & 2.588 to 3.939 & $3.158^{\star \star \star}$ & 2.481 to 4.020 & $2.701^{\star \star \star}$ & 2.125 to 3.434 & $3.129^{\star \star \star}$ & 2.498 to 3.920 & $2.816^{\star \star \star}$ & 2.127 to 3.730 \\
\hline Materially disadvantaged & $1.489^{* * *}$ & 1.185 to 1.872 & $1.483^{\star \star \star}$ & 1.150 to 1.912 & $1.469^{\star \star \star}$ & 1.137 to 1.899 & $1.523^{\star \star \star}$ & 1.190 to 1.950 & $1.509^{* * *}$ & 1.130 to 2.016 \\
\hline Indigenous & 1.120 & 0.793 to 1.583 & 1.228 & 0.838 to 1.800 & 1.231 & 0.842 to 1.799 & 1.234 & 0.857 to 1.777 & 1.432 & 0.931 to 2.202 \\
\hline Low family cohesion & $2.382^{\star \star \star}$ & 2.029 to 2.798 & $2.325^{\star \star \star}$ & 1.953 to 2.768 & $2.169^{\star \star \star}$ & 1.819 to 2.586 & $2.282^{\star \star \star}$ & 1.925 to 2.706 & $2.094^{* * *}$ & 1.723 to 2.544 \\
\hline High family cohesion & $0.692^{\star \star *}$ & 0.574 to 0.834 & $0.652^{\star \star \star}$ & 0.531 to 0.801 & $0.687^{\star \star \star}$ & 0.563 to 0.838 & $0.692^{\star \star \star}$ & 0.570 to 0.840 & $0.652^{\star * *}$ & 0.524 to 0.813 \\
\hline $\mathrm{FHC}$ & & & 1.195 & 0.717 to 1.992 & 1.527 & 0.844 to 2.762 & $2.840^{\star \star \star}$ & 1.464 to 5.509 & $1.778^{\star \star *}$ & 1.193 to 2.650 \\
\hline Year $8 \times \mathrm{FHC}$ & & & 1.234 & 0.783 to 1.944 & 1.253 & 0.759 to 2.068 & 0.636 & 0.358 to 1.131 & 0.889 & 0.622 to 1.269 \\
\hline Girl × FHC & & & 1.240 & 0.833 to 1.848 & 1.280 & 0.812 to 2.016 & 0.849 & 0.496 to 1.453 & 1.244 & 0.904 to 1.712 \\
\hline With disability $\times$ FHC & & & 0.810 & 0.489 to 1.343 & 1.358 & 0.779 to 2.367 & 0.985 & 0.502 to 1.931 & 0.969 & 0.626 to 1.501 \\
\hline Materially disadvantaged $\times \mathrm{FHC}$ & & & 0.903 & 0.498 to 1.635 & 0.692 & 0.382 to 1.252 & 0.620 & 0.314 to 1.221 & 0.766 & 0.474 to 1.238 \\
\hline Indigenous $\times$ FHC & & & 0.567 & 0.234 to 1.376 & 0.498 & 0.201 to 1.234 & $0.368^{*}$ & 0.121 to 1.117 & $0.458^{\star *}$ & 0.224 to 0.934 \\
\hline Low family cohesion $\times$ FHC & & & 1.114 & 0.705 to 1.762 & 1.392 & 0.867 to 2.234 & 1.243 & 0.716 to 2.160 & 1.346 & 0.942 to 1.924 \\
\hline High family cohesion $\times \mathrm{FHC}$ & & & 1.456 & 0.867 to 2.446 & 1.288 & 0.683 to 2.428 & 1.244 & 0.549 to 2.821 & 1.378 & 0.893 to 2.125 \\
\hline Constant & $0.284^{\star \star *}$ & 0.239 to 0.338 & $0.284^{\star \star \star}$ & 0.236 to 0.342 & $0.290^{\star \star \star}$ & 0.242 to 0.348 & $0.268^{\star \star \star}$ & 0.224 to 0.321 & $0.265^{\star \star \star}$ & 0.216 to 0.323 \\
\hline Log Likelihood (intercept only) & -2552.453 & & -2552.453 & & -2552.453 & & -2552.453 & & -2552.453 & \\
\hline Log Likelihood (full model) & -2364.304 & & -2350.158 & & -2328.059 & & -2350.192 & & -2322.647 & \\
\hline McFadden pseudo- $\mathrm{R}^{2}$ & 0.074 & & 0.079 & & 0.088 & & 0.079 & & 0.090 & \\
\hline Observations & 4237 & & 4237 & & 4237 & & 4237 & & 4237 & \\
\hline
\end{tabular}

Logistic regression model: two or more health symptoms at least weekly=f (girl, marginalised (with disability, materially disadvantaged, Indigenous), family cohesion and FHC, and interaction of

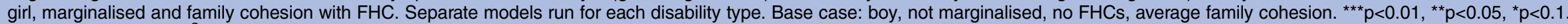
McFadden's pseudo- $R^{2}$ is calculated as $1-($ Log Likelihood (full model)/ Log Likelihood (intercept only)). Source: ACWP survey, authors' calculations. 
symptoms at least weekly) are significantly greater for those with FHCs than for those without. Almost half of years 4 and 6 students $(48.7 \%)$, and slightly fewer year 8 students $(44.2 \%)$ with any FHC reported experiencing two or more symptoms at least weekly; this compares with $27.7 \%$ and $24.3 \%$ of students in the two year groups without FHCs, respectively.

The table also shows that while there is no significant difference between boys and girls with FHCs reporting high symptom load in years 4 and 6 , girls are significantly more likely to report a high symptom load in year 8. Among students with disability and materially disadvantaged students in both year groups, those with FHCs are significantly more likely to report high symptom load than those without. Higher proportions of Indigenous students with FHCs in years 4 and 6 also report high symptom load than those without, although the difference is not statistically significant. In year 8 on the other hand, there is little difference in the proportions of Indigenous with and without FHCs reporting high symptom load. Finally, the table shows a strong association between level of family cohesion and proportions reporting a high symptom load, where, for younger and older students, lower family cohesion is associated with more negative symptoms.

It is worth noting that among younger and older students with FHCs, proportions with a high symptom load are lowest where the FHC is disability or chronic illness $(41.76 \%, 95 \%$ CI $35.01 \%$ to $48.52 \%$; and $41.74 \%$; $95 \%$ CI $36.59 \%$ to $46.88 \%$, respectively), and highest where the FHC relates to drug/alcohol addiction among years 4 and $6(60.0 \%$; $95 \%$ CI $49.51 \%$ to $70.49 \%)$ and mental illness among year 8 (55.3\%; 95\% CI $50.01 \%$ to $60.60 \%)$. The incidence of high symptom load therefore varies not only according to student characteristics, but also according to FHC type.

Table 3 shows ORs associated with having a high symptom load, where explanatory variables include age, sex, marginalisation and family cohesion, as well as the different FHC types. The odds are derived from logistic regression models where the explanatory variables (except for FHCs) are included (model 1), and interacted with FHC-disability (model 2), FHC-mental illness (model 3), FHC-drug/alcohol addiction (model 4) and any FHC (model 5). Model 1 results therefore show odds and 95\% CIs associated with each explanatory variable with no FHC indicators and no interactions, while the remaining model results show odds for each explanatory variable, and the marginal (multiplicative) effects of interaction with each of the FHC indicators. The odds for these interactions therefore represent the increased association between FHCs and high symptom load. It is worth noting that the small improvement in McFadden's pseudo- $\mathrm{R}^{2}$ for models $2-5$ over model 1 suggests that FHCs contribute only a small proportion of 'explained variation' in symptom load. ${ }^{44}$

Model 1, without interactions, shows that ORs of high symptom load for year 8 and high family cohesion are significantly $<1$; ORs for girl, with disability, materially disadvantaged and low family cohesion are all significantly $>1$. Odds for Indigenous, on the other hand, are not significantly different from 1 . None of these odds changes greatly in models $2-5$. Moreover, neither the indicators for FHC-disability (model 2) nor FHC-mental illness (model 3 ), nor their interactions, are significant, suggesting that these two types of FHC do not increase the odds of a student having a high symptom load, over and above the odds associated with the other explanatory variables. However, model 4 shows that the indicator for FHC-drug/ alcohol addiction is associated with significantly increased odds of a student having a high symptom load $(\mathrm{OR}=2.84$; 95\% CI 1.464 to $5.509 ; \mathrm{p}<0.01$ ). Model 4 also shows the Indigenous $\times$ FHC interaction being associated with significantly reduced odds of high symptom load $(\mathrm{OR}=0.37$; $95 \%$ CI 0.121 to $1.117 ; \mathrm{p}<0.1)$. Similarly to model 4 , model 5 (any FHC) shows that the FHC indicator and the Indigenous $\times \mathrm{FHC}$ interaction are significant. To summarise, therefore, having a family member with a disability or chronic illness, or mental illness, does not significantly increase the odds of a high symptom load. On the other hand, having a family member with a drug/alcohol addiction is associated with significantly greater marginal odds of a high symptom load.

\section{DISCUSSION}

This study, based on a nationally representative sample of students aged 9-14 years, suggests that approximately one-quarter of young Australians in their middle years have an FHC. This supports findings from a school and community study in Queensland where similar proportions of young people reported an FHC. The study shows that FHCs are more heavily concentrated among marginalised groups (young people with disability, materially disadvantaged young people and Indigenous young people) than among the non-marginalised. Among year 8 students, sex and scores on the family cohesion scale were also strongly associated with depression/mental illness and with drug/alcohol addiction, but not with disability/long-term illness. Variation by sex is notable among older students for two of the three FHC types (disability and mental illness), as is variation according to level of family cohesion (mental illness and drugs/alcohol). These findings add to those of Sieh et $a l^{8}$ and Pakenham and Cox,${ }^{7}$ who do not discuss prevalence in detail.

Consistent with Sieh et $a l^{8}$ and Pakenham and Cox, ${ }^{7}$ we found that that students with FHCs had poorer health than students without FHCs. This was true for younger and older students, although differences in symptom load were generally larger among the older students. The OR for the Indigenous $\times$ FHC-drug/alcohol addiction indicator was significantly $<1$, suggesting that while FHC-drug/alcohol addiction was associated with increased symptom load overall, this increase was moderated in the case of Indigenous students (it is worth 
noting that both these results flowed into the 'Any FHC' regression too). This finding needs further investigation. The number of Indigenous students in the analyses here is relatively small, and there is a significant amount of overlap between Indigenous and other marginalised categories, ${ }^{37}$ which may influence results.

Similar to the analysis presented above, Pakenham and $\mathrm{Cox}^{7}$ also found that while the demographic factors they examined (age, sex, relative disadvantage, ethnicity) did have an association with somatisation, health and total difficulties, "their impact is independent of the effect of the presence of a serious illness in the family" (p. 434). It is worth noting with respect to socioeconomic status that while Pakenham and Cox use an area-based indicator for relative disadvantage, the use of a finer grained family-level material disadvantage indicator in the present analysis does not suggest different conclusions. Similar to Sieh et $a l^{8}$ but unlike Pakenham and Cox, ${ }^{7}$ the present analysis found that the relationship between FHCs and health symptoms was not stronger for girls than for boys when other factors were taken into account. This lack of increased association with health for girls is somewhat surprising, given that the present paper's findings also show that older girls are more likely than boys to report FHCs, and because girls are more likely than boys to take on caring roles for sick or injured family members. ${ }^{45}$

The third research question examined whether family cohesion modified the relationship between FHCs and symptom load in young people. While there is clearly a relationship between FHCs, family cohesion and symptom load, the logistic regression showed that the relationship between family cohesion and symptom load is also independent of FHCs. In one sense, this is not surprising. The relationship between family cohesion and FHCs is perhaps not best seen through an independent effect (low family cohesion is associated with less optimal outcomes for young people across a broad range of circumstances), but more through the percentages in table 1, which show that among older students with FHC-mental illness and FHC-drug/alcohol addiction, proportions reporting low levels of family cohesion are notably higher than proportions reporting high levels of cohesion. Therefore, while there may be no evidence of an extra marginal effect of cohesion on young people's health in the context of FHCs, the probability of being in a low cohesion family is considerably higher for young people reporting mental health or drug/ alcohol addiction FHCs. It is also possible that reporting of FHCs is lower for children in families with high cohesion, perhaps due to perceived, rather than actual, absence of FHC in some high cohesion families. However, previous studies suggest that children are aware of parent's illness, even when parents do not believe their children recognise their health concerns. ${ }^{46}$ Regardless, there is certainly scope for further investigation around this, especially considering that the prevalence of FHCs is negatively associated with family cohesion for the FHCs with the greatest stigma attached (substance use and mental health ${ }^{47}$ ).

Our data add to evidence suggesting an inequitable burden on young people associated with FHCs, with that health burden strongest in the case of drug/alcohol addiction. We have good understanding of how adolescents and adults can experience shame and stigma in relation to a family member's substance use or mental health, sometimes due to the perception that they are responsible for it. ${ }^{47}$ However, findings about relationships between young people's characteristics, FHCs and health outcomes need to be placed in the context of findings about prevalence. Given that, in this study, FHCs were found to be more prevalent among older girls, and among young people in marginalised groups, and that mental illness/depression and drug/alcohol addiction in particular were more prevalent among young people in low cohesion families, it is fair to conclude that high levels of symptom load among young people with FHCs in marginalised groups warrant policy attention.

The cross-sectional design of the study limits the development of casual explanations for the findings discussed here. Additionally, no data were collected from students on who in their family had an FHC, or whether they lived with this person. Pakenham and $\operatorname{Cox}^{7}$ show that FHCs in parents tend to be associated with worse outcomes in young people than FHCs in other family members. Thus, it is possible that there are varying degrees of association between FHCs and health, depending on who in the family is unwell, that are not captured here. Findings with respect to Indigenous young people, which suggest a smaller association between FHC-drug/alcohol addiction and symptom load than is found among all young people, need further investigation. The sample of Indigenous students in this study is relatively small, and a larger study might usefully seek to validate the results for this group reported here.

Policy initiatives are important in this space. Linkage of support for young people with FHCs across community services, healthcare and schools is needed to reduce stress, and ensure better knowledge of risks for young people associated with FHCs. ${ }^{48}$ Stigma, such as that associated with FHCs, particularly mental health and substance use, is increasingly regarded as a factor contributing to health inequalities ${ }^{49}$ and must be targeted with a multilevel approach incorporating community and individual-level approaches. ${ }^{50}$ Further work regarding family dynamics may also provide insight into approaches for targeted family-based interventions.

Contributors Both authors have made substantial contributions to the conception, analysis and interpretation of the work. Both have contributed to drafting and revisions of the work and approve its final version. Both agree to be accountable for all aspects of the work.

Funding Research was funded by the Australian Research Council through a Linkage Grant (LP120100543), and supported by Partner Organisations: the Australian Government Department of Education and Training, the Australian 
Government Department of Social Services, the Australian Institute of Health and Welfare, and the Australian Bureau of Statistics.

Competing interests None declared.

Ethics approval Ethics approval was obtained from all necessary committees: Flinders University Social and Behavioural Research Ethics Committee, University of New South Wales Human Research Ethics Committee, and all the required permissions from State and/or Catholic educational departments (as appropriate).

Data sharing statement More information on the Australian Child Wellbeing Project is available from the project website: http://australianchildwellbeing. com.au/. Survey data used in this analysis are publicly available to authorised researchers through the Australian Data Archive. http://www.ada. edu.au/ada/01309.

Open Access This is an Open Access article distributed in accordance with the Creative Commons Attribution Non Commercial (CC BY-NC 4.0) license which permits others to distribute, remix, adapt, build upon this work noncommercially, and license their derivative works on different terms, provided the original work is properly cited and the use is non-commercial. See: http://creativecommons.org/licenses/by-nc/4.0/

\section{REFERENCES}

1. Currie C, Zanotti C, Morgan A, et al. Social determinants of health and well-being among young people. Health Behaviour in School-aged Children (HBSC) study: international report from the 2010/2009 Survey. Copenhagen, WHO Regional Office for Europe. 2012 (Health Policy for Children and Adolescents, No. 6) https://www.researchgate. net/profile/Oddrun_Samdal/publication/265034558_Social determinants_of_health_and_well-being_among_young_people/links/ 548ae0310cf225bf669e135e.pdf

2. Morgan A, Haglund BJ. Social capital does matter for adolescent health: evidence from the English HBSC study. Health Promot Int 2009;24:363-72.

3. Barlow JH, Ellard DR. The psychosocial well-being of children with chronic disease, their parents and siblings: an overview of the research evidence base. Child Care Health Dev 2006;32:19-31.

4. Reupert AE, J Maybery D, Kowalenko N. Children whose parents have a mental illness: prevalence, need and treatment. Med J Aust 2013;199(Suppl 3):S7-9.

5. Sharpe D, Rossiter L. Siblings of children with a chronic illness: a meta-analysis. J Pediatr Psychol 2002;27:699-710.

6. Maybery DJ, Ling L, Szakacs E, et al. Children of a parent with a mental illness: perspectives on need. Aust e-J Adv Mental Health 2005;4:78-88.

7. Pakenham $\mathrm{KI}$, Cox S. The effects of parental illness and other ill family members on the adjustment of children. Ann Behav Med 2014;48:424-37.

8. Sieh DS, Meijer AM, Oort FJ, et al. Problem behavior in children of chronically ill parents: a meta-analysis. Clin Child Fam Psychol Rev 2010;13:384-97.

9. Howe D, Batchelor S, Bochynska K. Estimating consumer parenthood within mental health services: a census approach. Aust e-J Adv Mental Health 2009;8:231-41.

10. Chronis AM, Lahey BB, Pelham WE, et al. Psychopathology and substance abuse in parents of young children with attention-deficit/ hyperactivity disorder. J Am Acad Child Adolesc Psychiatry 2003;42:1424-32.

11. Maybery DJ, Reupert AE, Patrick K, et al. Prevalence of parental mental illness in Australian families. The Psychiatrist 2009;33:22-6.

12. Pirkola $\mathrm{S}$, Isometsä $\mathrm{E}$, Aro $\mathrm{H}$, et al. Childhood adversities as risk factors for adult mental disorders. Soc Psychiatry Psychiatr Epidemiol 2005;40:769-77.

13. Lieb R, Isensee B, Höfler M, et al. Parental major depression and the risk of depression and other mental disorders in offspring: a prospective-longitudinal community study. Arch Gen Psychiatry 2002:59:365-74.

14. Hosseinpoor AR, Stewart Williams JA, Gautam J, et al. Socioeconomic inequality in disability among adults: a multicountry study using the world health survey. Am J Public Health 2013;103:1278-86.

15. Jan S, Essue BM, Leeder SR. Falling through the cracks: the hidden economic burden of chronic illness and disability on Australian households. Med J Aust 2012;196:29-31.
16. Glover JD, Hetzel DM, Tennant SK. The socioeconomic gradient and chronic illness and associated risk factors in Australia. Aust New Zealand Health Policy 2004;1:8.

17. Dawe $S$, Frye $S$, Best $D$, et al. Drug use in the family: impacts and implications for children (ANCD Research Paper No. 13). 2006.

18. O'Leary CM. Fetal alcohol syndrome: diagnosis, epidemiology, and developmental outcomes. J Paediatr Child Health 2004:40:2-7.

19. Vos T, Barker B, Begg S, et al. Burden of disease and injury in Aboriginal and Torres Strait Islander Peoples: the Indigenous health gap. Int J Epidemiol 2009;38:470-7.

20. Larson A, Gillies M, Howard PJ, et al. It's enough to make you sick: the impact of racism on the health of Aboriginal Australians. Aust $N$ Z J Public Health 2007;31:322-9.

21. McNeil J. Americans with disabilities: 1991-92. U.S. Bureau of the Census, Current Population Reports. Washington, DC: U.S. Government Printing Office, 1993.

22. Fombonne $\mathrm{E}$, Simmons $\mathrm{H}$, Ford T, et al. Prevalence of pervasive developmental disorders in the British Nationwide survey of child mental health. J Am Acad Child Adolesc Psychiatry 2001;40:820-7.

23. Singer GH, Floyd F. Meta-analysis of comparative studies of depression in mothers of children with and without developmental disabilities. Am J Ment Retard 2006;111:155-69.

24. Ravens-Sieberer U, Torsheim T, Hetland J, et al. Subjective health, symptom load and quality of life of children and adolescents in Europe. Int J Public Health 2009;54(Suppl 2):151-9.

25. Fekkes M, Pijpers FI, Fredriks AM, et al. Do bullied children get ill, or do ill children get bullied? A prospective cohort study on the relationship between bullying and health-related symptoms. Pediatrics 2006;117:1568-74.

26. Santalahti $\mathrm{P}$, Aromaa M, Sourander A, et al. Have there been changes in children's psychosomatic symptoms? A 10-year comparison from Finland. Pediatrics 2005;115:e434-42.

27. Zubrick SR, Lawrence DM, Silburn SR, et al. The Western Australian Aboriginal Child Health Survey: The Health of Aboriginal Children and Young People. Perth: Telethon Institute for Child Health Research, 2004. http://espace.library.curtin.edu.au/R? func=dbin-jump-full\&local_base=gen01-era02\&object_id=116886.

28. Jaffee SR, Caspi A, Moffitt TE, et al. Individual, family, and neighborhood factors distinguish resilient from non-resilient maltreated children: a cumulative stressors model. Child Abuse Neg 2007;31:231-53.

29. Johnson HD, LaVoie JC, Mahoney M. Interparental conflict and family cohesion predictors of loneliness, social anxiety, and social avoidance in late adolescence. $J$ Adolesc Res 2001;16:304-18.

30. Kliewer W, Murrelle L, Prom E, et al. Violence exposure and drug use in Central American youth: family cohesion and parental monitoring as protective factors. $J$ Res Adolescence 2006;16:455-78.

31. Ackard DM, Neumark-Sztainer D, Story M, et al. Parent-child connectedness and behavioral and emotional health among adolescents. Am J Prev Med 2006;30:59-66.

32. Park SK, Kim JY, Cho CB. Prevalence of Internet addiction and correlations with family factors among South Korean adolescents. Adolescence 2008;43:895.

33. Kuendig $\mathrm{H}$, Kuntsche EAA. Family bonding and adolescent alcohol use: moderating effect of living with excessive drinking parents. Alcohol Alcohol 2006;41:464-71.

34. Dickson L, Derevensky JL, Gupta R. Youth gambling problems: examining risk and protective factors. Int Gambling Stud 2008;8:25-47.

35. Benzies K, Mychasiuk R. Fostering family resiliency: a review of the key protective factors. Child Fam Soc Work 2009;14:103-14.

36. Orthner DK, Jones-Sanpei H, Williamson $\mathrm{S}$. The resilience and strengths of low-income families. Fam Relations 2004;53:159-67.

37. Redmond G, Skattebol J, Saunders P, et al. Are the kids alright? Young Australians in their middle years: Final report of the Australian Child Wellbeing Project: Flinders University, University of New South Wales and Australian Council for Educational Research. 2016. http:// research.acer.edu.au/well_being/5/

38. Lietz P, O'Grady E, Tobin M, et al. Australian Child Wellbeing Project Technical Report. Melbourne: Australian Council for Educational Research. 2015. http://research.acer.edu.au/cgi/ viewcontent.cgi?article $=1001 \&$ context=well_being

39. Clark TC, Fleming T, Bullen P, et al. Youth'12 Overview: The health and wellbeing of New Zealand secondary school students in 2012. Auckland, New Zealand: The University of Auckland, 2013.

40. Inchley J, Currie D, Young T, et al. Growing up unequal: gender and socioeconomic differences in young people's health and well-being. Health Behaviour in School-aged Children (HBSC) study: international report from the 2013/2014 Survey. Copenhagen, WHO 
Regional Office for Europe. 2016 (Health Policy for Children and Adolescents, No. 7)http://alkoholdialog.dk/wp-content/uploads/2016/ 08/HBSC-2016.pdf.

41. Currie $\mathrm{C}$, Molcho M, Boyce $\mathrm{W}$, et al. Researching health inequalities in adolescents: the development of the Health Behaviour in School-Aged Children (HBSC) Family Affluence Scale. Soc Sci Med 2008;66:1429-36.

42. Elgar FJ, De Clercq B, Schnohr CW, et al. Absolute and relative family affluence and psychosomatic symptoms in adolescents. Soc Sci Med 2013;91:25-31.

43. Dinisman T, Fernandes L, Main G. Findings from the First Wave of the ISCWeB Project: international perspectives on child subjective well-being. Child Indicators Res 2015;8:1-4.

44. Allen J, Le H. An additional measure of overall effect size for logistic regression models. J Educ Behav Stat 2008;33:416-41

45. Dearden C, Becker S. Young carers in the UK: the 2004 report. London: Carers UK, 2004.
46. Stallard P, Norman P, Huline-Dickens $S$, et al. The effects of parental mental illness upon children: a descriptive study of the views of parents and children. Clin Child Psychol Psychiatry 2004;9:39-52.

47. Corrigan PW, Watson AC, Miller FE. Blame, shame, and contamination: the impact of mental illness and drug dependence stigma on family members. J Fam Psychol 2006;20:239.

48. Australian Health Disaster Management Policy Committee. Fourth National Mental Health Plan: an agenda for collaborative government action in mental health 2009-2014: Department of Health and Ageing. 2009.

49. Hatzenbuehler ML, Phelan JC, Link BG. Stigma as a fundamental cause of population health inequalities. Am J Public Health 2013;103:813-21

50. Cook JE, Purdie-Vaughns V, Meyer IH, et al. Intervening within and across levels: a multilevel approach to stigma and public health. Soc Sci Med 2014;103:101-9. 